UDK: 343.7(497.1)

Originalan naučni rad

Biblid: 1451-3188, 20 (2021)

Primljen

God XX, br. 76, str. 43-55

DOI: https://doi.org/10.18485/iipe_ez.2021.20.76.3

Odobren

\title{
ZAŠTITA IMOVINSKO-PRAVNIH INTERESA NA UPOREDNOM PRIMERU BIVŠIH REPUBLIKA SFRJ
}

\author{
Dragan MARKOVIĆ* \\ Danilo KOVAC $\check{C}^{* *}$
}

\begin{abstract}
Apstrakt: Cilj istraživanja je organizacija i nadležnost ustanova koje se bave zaštitom imovinsko-pravnih interesa u bivšim republikama SFRJ. Do saznanja o ovome došlo se prvenstveno primenom pravno-dogmatskog metoda, a tamo gde se to smatralo potrebnim i uporednopravnim, pravnosociološkim i filozofskim metodima. Istraživanje je rezultiralo saznanjima o poziciji ustanova koje se bave zaštitom imovinsko-pravnih interesa u državama nastalim od bivših republika SFRJ, njihovoj organizaciji i nadležnosti, načinu izbora, delokrugu rada kao i različitosti koja se, pre svega, ogleda u pozicioniranju pravobranilaštva uz jednu od grana vlasti. U zaključku su sumirani rezultati i date preporuke.

Ključne reči: zastupnička, savetnička, posrednička i institucionalna funkcija, interakcija, vladavina prava.
\end{abstract}

\section{1) UVOD}

Pravobranilaštvo je organ javne vlasti koji obavlja poslove pravne zaštite pre svega države, ali i drugih javnih subjekata kao što su autonomne pokrajine ili jedinice lokalne samouprave. Pravobranilaštvo zastupa državu ili druge subjekte javne vlasti kao stranku u postupku pred sudovima ili drugim državnim organima, a može delovati i kao savetnik države ili drugih subjekata javne vlasti, odnosno njihovih organa.

\footnotetext{
* Major Vojske Srbije, pravobranilački pomoćnik u Vojnom pravobranilaštvu, odeljenje u Nišu Ministarstva odbrane.

${ }^{*}$ Kapetan policije, pomoćnik komandira Policijske ispostave Novi Beograd 2 Ministarstva unutrašnjih poslova, e-mail: markovicdragan80@gmail.com.
} 
Pod pravobranilaštvom ne podrazumevamo nužno samo jedan organ odnosne države koji nosi naziv koji bi se na srpski jezik tradicionalno preveo kao pravobranilaštvo, ili u doslovnom prevodu, najčešće, kao državna advokatura. Naprotiv, pod pravobranilaštvom podrazumevamo svaki državni organ koji je nosilac pravobranilačke funkcije ili nekih segmenata te funkcije. To može biti jedan poseban državni organ, mada je moguće i odrediti više različitih nosilaca pravobranilačke funkcije jedne države, kada je vršenje te funkcije podeljeno između različitih državnih organa. Takođe, moguće je da organ koji je određen kao glavni ili kao jedini nosilac pravobranilačke funkcije, pored poslova koji čine pravobranilačku funkciju, obavlja i neke druge poslove. ${ }^{1}$

\section{2) PRAVOBRANILAČKA DELATNOST U BIVŠIM REPUBLIKAMA SFRJ}

Nakon osamostaljivanja bivših republika SFRJ i sticanja nezavisnosti, svaka je ponaosob uredila vršenje pravobranilačke funkcije odstupajući, u većoj ili manjoj meri, od nekadašnjeg uređenja pravobranilaštva u nekadašnjoj zajedničkoj državi. U svim bivšim jugoslovenskim republikama postoji samo po jedan državni organ koji vrši funkciju državnog pravobranilaštva, koji zastupaju državu i sve njene organe, sem Republike Srbije, gde pored Državnog pravobranilaštva funkcioniše i Vojno pravobranilaštvo kao posebna organizaciona jedinica Ministarstva odbrane, koja preduzima pravne radnje i pravna sredstva radi ostvarivanja i zaštite imovinskih prava i interesa Republike Srbije u pogledu sredstava koja koriste Ministarstvo odbrane i Vojska Srbije.

\subsection{SLOVENIJA}

U Republici Sloveniji poslove pravobranilaštva obavlja Državno odvetništvo, osnovano Zakonom o državnom odvetništvu 2017. godine, kada je prestalo sa radom Državno pravobranilaštvo Republike Slovenije.

Na čelu Državnog odvetništva je državni odvetnik, koga na obrazloženi predlog ministra pravde imenuje Vlada nakon pribavljenog mišljenja Komisije za procenu podobnosti kandidata na period od šest godina, sa mogućnošću ponovnog imenovanja. Zamenika državnog odvetnika takođe imenuje Vlada, na predlog državnog odvetnika uz saglasnost ministra pravde na period od šest godina.

Državno odvetništvo obavlja stručne poslove u oblasti zaštite imovine i drugih prava i interesa države putem pravnog zastupanja pred sudovima i upravnim organima u Republici Sloveniji, pred stranim sudovima i stranim arbitražama i

\footnotetext{
${ }^{1}$ Olja Jovičić, „Istorija pravobranilaštva u Srbiji”, Bilten Republičkog javnog pravobranilaštva, br. 2/2013, Intermeks, Beograd, str. 11-12.
} 
pred međunarodnim sudovima i međunarodnim arbitražama. Takođe, obavlja poslove pravnog savetovanja, mirnog rešavanja sporova u prethodnom postupku i druge poslove utvrđene Zakonom o državnom odvetništvu ili drugim zakonima.

Svako ko namerava da pokrene građanski ili drugi postupak protiv države ili državnog organa mora predložiti Državnom odvetništvu da se sporni odnos reši sporazumno pre pokretanja građanskog ili drugog postupka, s tim da je takav prethodni postupak uslov za pokretanje građanskog ili drugog postupka. Stranka koja namerava da pokrene parnični ili drugi postupak protiv države ili državnog organa, dužna je da nadležnom sudu ili drugom organu dostavi potvrdu o neuspelom pokušaju mirnog rešenja spora u prethodnom postupku.

Sedište Državnog odvetništva je u Ljubljani dok se odseci nalaze još u osam gradova. Bitno je istaći da je Državno odvetništvo u Ljubljani isključivo nadležno za vođenje sledećih postupaka:

- zastupanje javnog interesa u upravnim sporovima;

- zastupanje pred stranim sudovima i stranim arbitražama i međunarodnim sudovima i međunarodnim arbitražama;

- zastupanje u postupcima za reparaciju, rehabilitaciju i izvršenje drugih prava lica koja su neopravdano osuđena ili neopravdano lišena slobode prema zakonu kojim se uređuje krivični postupak, ili koja su neopravdano sankcionisana ili neopravdano lišena slobode prema zakonu kojim se uređuju prekršaji;

- zastupanje u postupcima za reviziju postupaka javnih nabavki;

- izvršavanje zadataka koje je dodelio državni odvetnik uz prethodnu saglasnost ministra iz razloga efikasnosti ili bolje kvalifikacije sedišta Državnog pravobranilaštva.

\subsection{HRVATSKA}

U Republici Hrvatskoj isti organ obavlja javnotužilačku i pravobranilačku funkciju. Državno odvjetništvo samostalno je i nezavisno pravosudno telo ovlašćeno da postupa protiv izvršilaca krivičnih dela i preduzima pravne radnje radi zaštite imovine Republike Hrvatske, te je s tim ciljem u okviru Državnog odvjetništa formiran građansko-upravni odjel, na čijem čelu se nalazi voditelj odjela, koji se bavi zaštitom imovine i imovinskih interesa Republike Hrvatske i preduzimanjem radnji radi zaštite Ustava i zakona. Državno odvjetništvo kao zastupnik po zakonu Republike Hrvatske preduzima pravne radnje radi zaštite njene imovine i imovinskih interesa u postupcima pred sudovima, upravnim i drugim telima.

Takođe, postupanjem kao stranka sui generis u upravnim sporovima, podizanjem zahteva za vanredno ispitivanje zakonitosti pravnosnažnih presuda upravnog suda, u upravnim postupcima radi povraćaja oduzete imovine kao i u 
drugim slučajevima kada je posebnim zakonom dato ovlašćenje državnom odvjetništvu da preduzima pravne radnje u svoje ime, državno odvjetništvo postupa u cilju zaštite zakonitosti. Građansko-upravni odjel u okviru Državnog odvjetništva nadležan je i za davanje pravnih mišljenja na pravne poslove koje sklapa Republika Hrvatska, kao jedna od ugovornih strana, istovremeno štiteći zakonitost, osigurava pravedno i jednako postupanje prema svima, prevenira nastanak sporova, ali i štiti imovinske interese Republike Hrvatske.

Državno odvjetništvo Hrvatske ustanovljeno je za celo područje države, a uspostavljena su i županijska i opštinska odvjetništva kao i posebna odvjetništva za postupanje u određenim vrstama predmeta. Općinska državna odvjetništva postupaju pred općinskim sudovima i javnopravnim telima. Županijska državna odvjetništva postupaju pred županijskim, trgovačkim i upravnim sudovima, dok posebna državna odvjetništva postupaju pred sudovima određenim zakonom. Takođe, Državno odvjetništvo zastupa Republiku Hrvatsku pred stranim sudovima i međunarodnim i drugim telima.

Glavnog državnog odvjetnika Republike Hrvatske na period od četiri godine imenuje Hrvatski sabor na predlog Vlade uz prethodno mišljenje nadležnog odbora Sabora. Uz Državno odvjetništvo Republike Hrvatske i Ureda za suzbijanje korupcije i organiziranog kriminaliteta (USKOK), organizacija Državnog odvjetništva obuhvata 15 županijskih državnih odvjetništava i 25 opštinskih.

\subsection{BOSNA I HERCEGOVINA}

Pravobranilačka delatnost u Bosni i Hercegovini ustanovljena je Zakonom o Pravobranilaštvu Bosne i Hercegovine u cilju da se državi obezbedi mogućnost efikasne zakonske zaštite i zastupanja u pogledu zaštite njenih Ustavom utvrđenih nadležnosti, interesa i prava. Pravobranilaštvo Bosne i Hercegovine je organ nadležan za vršenje poslova pravne zaštite imovine i imovinskih interesa, njenih institucija i drugih organizacija koje se finansiraju iz budžeta. Navedene zadatke Pravobranilaštvo obavlja kroz vršenje poslova zakonskog zastupanja navedenih subjekata pred sudovima i drugim nadležnim organima, kao i pravnog savetovanja. Funkciju Pravobranilaštva vrše pravobranilac, dva zamenika pravobranioca i više pomoćnika pravobranioca.

Pravobranilaštvom Bosne i Hercegovine rukovodi pravobranilac, koga u slučaju odsutnosti ili sprečenosti zamenjuje zamenik koga on odredi. Prilikom izbora pravobranioca, zamenika pravobranioca i pomoćnika pravobranioca vodi se računa o ravnomernoj zastupljenosti konstitutivnih naroda Bosne i Hercegovine. Nadležnosti Pravobranilaštva Bosne i Hercegovine određene su prioritetno Zakonom o Pravobranilaštvu Bosne i Hercegovine. Pravobranilaštvo u skladu sa predmetnim zakonom obavlja poslove zastupanja institucija koje se finansiraju iz budžeta $\mathrm{BiH}$ pred Sudom $\mathrm{BiH}$, i institucija $\mathrm{BiH}$ u upravnom postupku, pred sudovima i drugim organima u entitetima, kao i pred sudom Brčko distrikta i 
organima uprave u Brčko distriktu. Takođe, Pravobranilaštvo može zastupane subjekte zastupati u upravnom sporu ako ga oni za to ovlaste. Pred Ustavnim sudom BiH Veće ministara BiH zastupa Pravobranilaštvo.

Pravobranilaštvo $\mathrm{BiH}$ zastupa $\mathrm{BiH}$ i njene institucije pred međunarodnim sudovima, sudovima drugih država, međunarodnim arbitražama i organima drugih država, kao i pred arbitražom koja je predviđena članom VIII Sporazuma između NATO snaga i država koje učestvuju u Partnerstvu za mir o pravnom položaju njihovih snaga. U skladu sa zahtevom entiteta i Brčko distrikta, Pravobranilaštvo BiH može zastupati Federaciju BiH i Republiku Srpsku, kao i Brčko distrikt, pred inostranim sudovima, arbitražama, tribunalima i drugim inostranim državnim organima i organizacijama.

U postupku donošenja zakona i drugih propisa kojima se uređuju imovinskopravni odnosi, a stiču prava i stvaraju obaveze prema stvarima u vlasništvu $\mathrm{BiH}$, obavezno se pribavlja mišljenje Pravobranilaštva BiH. Sve institucije BiH koje se finansiraju iz budžeta dužne su da od Pravobranilaštva pribave mišljenje u vezi sa zaključivanjem ugovora imovinsko-pravne prirode ukoliko vrednost ugovora prelazi zakonom utvrđen novčani iznos. Pravobranilac predstavlja Pravobranilaštvo Bosne i Hercegovine i rukovodi njegovim radom. Pravobranioca Bosne i Hercegovine imenuje i razrešava Savet ministara Bosne i Hercegovine. Poslovi osnovne delatnosti vrše se u okviru šest organizacionih jedinica koje su nosioci pravobranilačke funkcije i vrše ih pomoćnici pravobranioca.

\subsection{REPUBLIKA SRPSKA}

Zakonom o Pravobranilaštvu Republike Srpske propisano je da je Pravobranilaštvo samostalan organ koji u postupku pred sudovima i drugim nadležnim organima preduzima pravna sredstva radi zaštite i ostvarivanja imovinskih prava i interesa zastupanih subjekata, te vrši i druge poslove određene zakonom. Zastupani subjekat su Republika Srpska, jedinica lokalne samouprave, njihovi organi i organizacije, te drugi organi i organizacije koje nemaju svojstvo pravnog lica i nisu upisani u sudski registar, a finansiraju se iz budžeta Republike Srpske.

Nadležnosti Pravobranilaštva Republike Srpske utvrđene su odredbama Zakona o Pravobranilaštvu Republike Srpske, prema kojima obavlja sledeće poslove:

- kao samostalan organ u postupku pred sudovima i drugim nadležnim organima preduzima pravna sredstva radi zaštite i ostvarivanja imovinskih prava i interesa zastupanih subjekata;

- vrši poslove zastupanja u sudskim i upravnim i drugim postupcima;

- kao samostalan organ ima pravo i obavezu da pokrene, odnosno podnese inicijativu za pokretanje postupka ili se uključi u postupak pred sudom ili 
drugim nadležnim organom radi zaštite prava i interesa zastupanih subjekata u slučajevima kada je to propisano zakonom, kada to pismeno zahtevaju subjekti koje ono zastupa ili kada na drugi način sazna da je to potrebno;

- prati i proučava pojave, pravna pitanja i probleme od značaja za vršenje svojih nadležnosti, imovinu zastupanih subjekata, primjenu zakona i drugih propisa, te obavještava Vladu i druge nadležne organe i predlaže mere za zaštitu imovine zastupanih subjekata i sprečavanje društveno štetnih pojava;

- Pravobranilaštvo je obavezno da pred Ustavnim sudom pokrene postupak za ocenu ustavnosti zakona i zakonitosti drugih propisa i opštih akata, kada oceni da su povređena imovinska prava i interesi zastupanih subjekata;

- Pravobranilaštvo je obavezno da traži poništavanje ili ukidanje odluka i drugih akata kojima su povređena imovinska prava zastupanih subjekata,

- u postupcima utvrđivanja krivične odgovornosti za krivična dela za koja postoji osnovana sumnja da je nastala materijalna šteta za zastupanog subjekta, Pravobranilaštvo je dužno da učestvuje u svojstvu zastupnika oštećenog, po obaveštenju nadležnog organa ili u drugim slučajevima kada sazna da je to potrebno;

- u cilju zaštite imovinskih prava i interesa zastupanih subjekata daje obrazloženo mišljenje tim subjektima na nacrte privrednih ugovora, ugovora o koncesijama, ugovora o javno-privatnim partnerstvima i ugovora koji regulišu imovinsko-pravna pitanja, uz obavezu dostavljanja relevantne dokumentacije od strane zastupanog subjekta;

- daje mišljenja subjektima koje po zakonu zastupa i u drugim pravnim stvarima kada zastupani subjekt smatra da je to potrebno;

- podnosi tužbu za utvrđivanje ništavosti, odnosno tužbu za poništenje ugovora koji je zaključio zastupani subjekt, a za koji ugovor je Pravobranilaštvo mišljenja da je ništavan, odnosno rušljiv;

- pre pokretanja postupka pred nadležnim sudom ili drugim organom, preduzima mere radi pokušaja zaključenja vansudskog poravnanja;

- učestvuje u postupcima medijacije ukoliko za to ima izričitu pismenu saglasnost zastupanog subjekta;

$\mathrm{Na}$ čelu Pravobranilaštva se nalazi pravobranilac koga postavlja Narodna skupština, kao i zamenika pravobranioca na period od četiri godine uz mogućnost ponovnog izbora. Nakon ponovnog izbora funkcija zamenika je stalna. Pravobranilaštvo je organizovano sa sedam sedišta zamenika pravobranioca.

\subsection{FEDERACIJA BiH}

Poslove zaštite imovinsko-pravnih interesa Federacije BiH vrši Federalno pravobraniteljstvo koje predstavlja poseban samostalni organ, koji preduzima 
mere i pravna sredstva radi pravne zaštite imovine imovinskih interesa Federacije $\mathrm{BiH}$. Federalno pravobraniteljstvo obavlja poslove pravne zaštite imovine imovinskih interesa Federacije i njenih organa i tela koja nemaju svojstvo pravnog lica, a finansiraju se iz budžeta Federacije. Pored poslova određenih zakonom, Federalno pravobraniteljstvo zastupa Federaciju pred stranim sudovima, arbitražama i drugim stranim državnim organima i organizacijama, kao i državne organe koji su tuženi u upravnom sporu ako ga ona za to ovlaste, kada je povređena imovina i imovinski interesi Federacije. U postupcima donošenja opštih akata, kojima se uređuju imovinsko-pravni odnosi, prava i obaveze prema stvarima u Vlasništvu Federacije, obavezno se pribavlja mišljenje federalnog pravobranitelja.

U okviru svojih redovnih zadataka Federalno pravobraniteljstvo pruža stručnu pomoć organima, fondovima, preduzećima i drugim pravnim licima u rešavanju imovinsko-pravnih pitanja i daje mišljenje u vezi sa zaključivanjem ugovor imovinsko-pravne prirode, ukoliko vrednost ugovora prelazi zakonom utvrđen novčani iznos.

Na čelu Federalnog pravobraniteljstva nalazi se federalni pravobranitelj. Predlog za imenovanje federalnog pravobranitelja i njegovog zamenika podnosi ministar pravde, imenuje ih i postavlja premijer uz saglasnost zamenika premijera i uz potvrdu Parlamenta Federacije BiH. Dok se federalni pravobranitelj imenuje na period od četiri godine i može biti ponovo imenovan, njegov zamenik imenuje se za vršenje službe bez ograničenja. Broj zamenika federalnog pravobranitelja utvrđuje Vlada na predlog federalnog ministra pravde. U federalnom pravobraniteljstvu postoji određeni broj promoćnika federalnog pravobranitelja radi obavljanja stručnih poslova, koje postavlja federalni pravobranitelj i koji pred sudovima i drugim organima imaju ovlašćenja koja odredi federalni pravobranitelj.

\subsection{SRBIJA}

Poslove zaštite imovinskih prava i interesa Republike Srbije obavlja Državno pravobranilaštvo, izuzev u postupcima koji za predmet imaju prava i obaveze Republike Srbije u vezi sa delokrugom ministarstva nadležnog za poslove odbrane, vojnih jedinica i vojnih ustanova koje su organizaciono vezane za ministarstvo nadležno za poslove odbrane i Vojsku Srbije koje obavlja Vojno pravobranilaštvo.

Državno pravobranilaštvo je zastupnik Republike Srbije u pravnim postupcima pred sudovima, arbitražama, organima uprave i drugim nadležnim organima, kada Republika Srbija ima položaj stranke ili umešača o čijim pravima i obavezama se odlučuje u tom postupku. Takođe, zastupa državu i pred stranim i međunarodnim sudovima i arbitražama, pred Evropskim sudom za ljudska prava.

Državno pravobranilaštvo pred sudovima, arbitražama i organima uprave i drugim nadležnim organima zastupa državne organe i posebne organizacije koji nemaju svojstvo pravnog lica, a čije se finansiranje obezbeđuje iz budžeta Republike Srbije i javne ustanove čiji je osnivač država, a čije se finansiranje 
obezbeđuje iz republičkog budžeta, u pravnim postupcima u kojima ovi subjekti učestvuju kao stranke ili umešači o čijim imovinskim pravima i obavezama se odlučuje u tom postupku. Državno pravobranilaštvo može na osnovu posebno datog punomoćja zastupati u postupku pred sudovima, arbitražama, organima uprave i drugim nadležnim organima i druga pravna lica čiji je osnivač država.

Takođe, Državno pravobranilaštvo prati i proučava pravna pitanja od značaja za rad državnih organa, kao i primenu zakona i drugih opštih akata, kada je to od značaja za zaštitu imovinskih prava i interesa Republike Srbije može pokrenuti postupak za ocenu ustavnosti zakona, odnosno zakonitosti drugih opštih pravnih akata, ako oceni da su njima povređeni prava i imovinski interesi države i daje pravna mišljenja na nacrte pravnih poslova koje zaključuju subjekti koje zastupa. Državnog pravobranioca i njegovog zamenika, na predlog ministra nadležnog za pravosuđe, postavlja Vlada na period od pet godina, dok nadzor nad radom vrši ministarstvo nadležno za pravosuđe po službenoj dužnosti, po zahtevu sudova, arbitraža, organa uprave ili na inicijativu stranaka i učesnika u postupku.

Vojno pravobranilaštvo je posebna organizaciona jedinica Ministarstva odbrane koja preduzima pravne radnje i pravna sredstva radi ostvarivanja i zaštite imovinskih prava i interesa Republike Srbije u pogledu sredstava koja koriste Ministarstvo odbrane i Vojska Srbije. U zastupanju Ministarstva odbrane i Vojske Srbije pred sudovima i drugim nadležnim organima, Vojno pravobranilaštvo ima položaj zastupnika Republike Srbije - Ministarstva odbrane i Vojske Srbije s pravima i dužnostima propisanim za državno pravobranilaštvo, osim zastupanja pred stranim i međunarodnim sudovima i arbitražama, i pred drugim nadležnim organima u inostranstvu.

Vojno pravobranilaštvo je ovlašćeno da pokrene postupak za ocenu ustavnosti i zakonitosti propisa i opštih pravnih akata ako oceni da su njima povređena imovinska prava i interesi Republike Srbije u pogledu sredstava koja koriste Ministarstvo odbrane i Vojska Srbije za potrebe odbrane i bezbednosti, ili zakonom utvrđen položaj Vojske Srbije. Takođe, daje i pravna mišljenja na modele, odnosno nacrte pravnih poslova koje Ministarstvo odbrane i Vojska Srbije zaključuju sa drugim pravnim subjektima, ako ti pravni poslovi za predmet imaju imovinska prava i obaveze Ministarstva odbrane i Vojske Srbije.

Vojnog pravobranioca i zamenike vojnog pravobranioca postavlja ministar odbrane, uz ispunjenje uslova propisanih za postavljenje državnog pravobranioca, odnosno zamenika državnog pravobranioca. Organizaciju rada i uređenje Vojnog pravobranilaštva, shodno propisima za rad pravobranilaštva Republike Srbije, uređuje ministar odbrane uz saglasnost Vlade.

\subsection{CRNA GORA}

U Crnoj Gori je 1993. godine, Zakonom o državnom tužilaštvu, prestala sa radom institucija Javnog pravobranilaštva, a zakonsko zastupanje Crne Gore prešlo 
je u nadležnost Državnog tužilaštva. Ovaj način zaštite imovinskih prava i interesa Crne Gore trajao je do donošenja Zakona o državnoj imovini 2009. godine, kojim je uspostavljen Zaštitnik imovinsko-pravnih interesa kao samostalni organ.

Prema Zakonu o državnoj imovini Zaštitnik imovinsko-pravnih interesa Crne Gore zastupa pred sudovima i drugim državnim organima u svojstvu zakonskog zastupnika Crnu Goru, njene organe i javne službe čiji je osnivač država, a nemaju svojstvo pravnog lica. U slučajevima kada to priroda spora dopušta, pre pokretanja parnice ili drugog postupka preduzima potrebne mere radi sporazumnog rešavanja spornog odnosa.

Takođe, zaštitnik imovinsko-pravnih interesa Crne Gore daje organima čija imovinska prava i interese zastupa, na njihov zahtev, pravna mišljenja u vezi sa zaključivanjem imovinsko-pravnih ugovora i pravna mišljenja o drugim imovinsko-pravnim pitanjima. Funkciju ovog državnog organa obavlja državni funkcioner - zaštitnik imovinsko-pravnih interesa Crne Gore, kojeg imenuje i razrešava Vlada na predlog ministra finansija, sa mandatom od pet godina. Zaštitnik ima jednog ili više zamenika koje imenuje i razrešava Vlada na predlog zaštitnika, sa mandatom od pet godina. Zaštitnik imovinsko-pravnih interesa deluje na teritoriji Crne Gore kao jedinstven organ - bez podele nadležnosti po mesnom i stvarnom principu, što predstavlja rešenje koje omogućava postupanje pred svim sudovima i organima uprave. Nadzor nad radom zaštitnika imovinskopravnih interesa vrši Ministarstvo finansija.

\subsection{SEVERNA MAKEDONIJA}

Na osnovu zakona o državnom pravobranilaštvu Republike Severne Makedonije, Državno pravobranilaštvo je organ koji preduzima mere i pravna sredstva radi pravne zaštite imovine i interesa Republike Severne Makedonije. Državni pravobranilac i državni pravobranioci štite imovinska prava i interese Republike Severne Makedonije i državnih organa osnovanih zakonom pred sudovima i drugim organima u zemlji i inostranstvu.

Državnim pravobranilaštvom rukovodi državni pravobranilac kog imenuje Vlada na predlog Ministarstva pravde na period od šest godina. Državne pravobranioce imenuje Vlada po prethodno pribavljenom mišljenju državnog pravobranioca bez ograničenja trajanja mandata. Vlada na predlog državnog pravobranioca određuje broj državnih pravobranilaca uz određivanje sedišta državnih pravobranilaca i njihove mesne nadležnosti.

\section{3) FUNKCIJE PRAVOBRANILAŠTVA U BIVŠIM REPUBLIKAMA SFRJ - SLIČNOSTI I RAZLIKE}

Proučavajući pozitivnopravne propise kojima se definiše uređenje, organizacija i nadležnost organa javne vlasti koji obavljaju poslove imovinsko-pravne zaštite 
države i drugih javnih subjekata možemo uočiti kako sličnosti tako i razlike u samom uređenju i njihovoj organizaciji. Nadležnost, zadaci i delokrug rada pravobranilačkih organa u bivšim republikama SFRJ je uglavnom ista. Zastupnička funkcija se ogleda u zastupanju države ili drugih subjekata javne vlasti kao stranke u postupku pred sudovima ili drugim državnim organima, kao i zastupanje pred međunarodnim sudovima, sudovima drugih država i međunarodnim arbitražama. Iako zakonskim aktima koji regulišu rad pravobranilaštava nije izričito predviđeno, zastupnička funkcija podrazumeva i zastupanje države kao dužnika u postupku izvršenja. S tim u vezi stav Evropskog suda za ljudska prava o prinudnom izvršenju protiv države je jasan:

„U postupcima protiv države, u kojima država izgubi, izvršenje presude mora nastupiti automatski” ${ }^{2}$ ili „Ako je presuda doneta protiv nekog javnog organa, ona mora biti automatski izvršena”, te „Sud je naglasio da finansijske teškoće s kojima se država suočava ne mogu biti opravdanje za neizvršenje onoga što je presudom naloženo". ${ }^{4}$

U nadležnosti pravobranilačkih organa je i davanje pravnog mišljenja na ugovore koje država zaključuje sa drugim pravnim subjektima, ako ti pravni poslovi za predmet imaju imovinska prava i obaveze države. Ta savetnička funkcija pravobranilaštva može se ostvarivati dvojako i to u zavisnosti od zakonskih rešenja predmetne funkcije. Dok se u pojedinim državama predmetno mišljenje daje na nacrt ugovora pre njegovog zaključenja, kao što je slučaj u Srbiji, u drugim se pravno mišljenje daje na već zaključeni ugovor, recimo u Republici Srpskoj, s tim u vezi i konkretna odredba Zakona o pravobranilaštvu Republike Srpske, kojom se uređuje ovlašćenje pravobranilaštva u vezi predmetnog ovlašćenja. ${ }^{5} \mathrm{U}$ BiH se ide korak dalje, i daju se šira ovlašćenja pravobranilaštvu u oceni ugovora koji za predmet imaju imovinsko-pravne odnose. ${ }^{6}$

Smatramo da je predmetno rešenje, gde se pravno mišljenje daje pre samog zaključenja ugovora, na nacrt, dosta praktičnije i u velikoj meri isključuje

${ }^{2}$ Glaser v. United Kingom, 19. septembar 2000. i Immobiliare Saffi v. Italy, 28. jul 1999, prema: Nula Mol, Katarina Harbi, „Pravo na pravično suđenje: Vodič za primjenu člana 6. Evropske konvencije o ljudskim pravima", Savet Evrope, Beograd, 2007. str. 19.

${ }^{3}$ Ibid, Hornsby v. Greece, 19. mart 1997. i Burdov v. Russia, 7. maj 2002, str. 14.

${ }^{4}$ Ibid, Burdov v. Russia, str. 19.

${ }^{5}$ Član 23 stav 2 Zakona o pravobranilaštvu Republike Srpske: „Ako pravobranilaštvo ocjeni da je zaključeni ugovor ništavan, podnijeće tužbu za utvrđivanje ništavosti, a u slučaju da je ugovor rušljiv, podnijeće tužbu za poništenje".

${ }^{6}$ Član 13 stav 17 Zakona o pravobranilaštvu BiH: „Ako pravobranilaštvo smatra da je zaključeni ugovor ništavan, podnijet će Sudu BiH tužbu za utvrđenje ništavosti, a u slučaju da ugovorena cijena ne odgovara prometnoj vrijednosti - tužbu za raskid ili izmijenu ugovora". 
mogućnost stvaranja kasnijih problema. Takvim zakonskim rešenjem se prevenira mogućnost da pravni poslovi koji se zaključuju budu u nesaglasnosti za Zakonima i drugim podzakonskim aktima, te da se već zaključeni pravni poslovi oglašavaju rušljivim ili ništavim. U nadležnosti pravobranilačkih organa je i pokretanje postupaka za ocenu ustavnosti i zakonitosti drugih propisa i opštih akata kada su povređena prava zastupanih subjekata.

Takođe, u pojedinim državama sa teritorije bivše SFRJ, kao što je slučaj sa Slovenijom, važećom zakonskom regulativom predviđeno je da stranka koja namerava da pokrene parnični ili drugi postupak protiv države ili državnog organa, dužna je da nadležnom sudu ili drugom organu dostavi potvrdu o neuspelom pokušaju mirnog rešenja spora u prethodnom postupku. S druge strane, imamo slučaj Srbije gde je u ranijim propisima koji regulišu oblast građansko-pravne materije bilo predviđeno da lice koje namerava da podnese tužbu protiv Republike Srbije, dužno je da pre podnošenja tužbe Republičkom javnom pravobranilaštvu dostavi predlog za mirno rešavanje spora, kao posebnoj procesnoj pretpostavci, čiji je nedostatak predstavljao razlog za odbacivanje tužbe. Kasnijim izmenama i dopunama Zakona o parničnom postupku ovakva mogućnost mirnog rešenja spora je izbačena iz zakona.

Iako pojedini autori smatraju da se predmetnim zakonskim rešenjem favorizovala država da "Jedino kada država treba da bude tužena uveden je princip obavezne medijacije mimo opšteg režima zasnovanog na dobrovoljnosti (...). Umesto da se u sudskom postupku štite autonomija i dispozicija parničnih stranaka, kao principi primereni zaštiti subjektivnih građanskih prava, sudski postupak je postao instrument za zaštitu države od stranačke autonomije. Ratio legis ovakve norme je nelegitiman, jer je zasnovan na diskriminaciji ostalih stranaka u odnosu na državu koja je tužena." ${ }^{7}$ Smatramo da ovakva odredba u Zakonu o parničnom postupku nikako nije favorizovala državu u odnosu na stranke i to iz više razloga. Pre svega, podnošenje predloga za mirno rešenje spora može samo ubrzati postupak naknade štete, ili ostvarivanja nekog prava iz razloga što je država solventna, i ukoliko je istaknuti imovinsko-pravni zahtev osnovan velika je verovatnoća da će se mnogo brže rešiti u postupku vansudskog poravnanja nego u parničnom postupku. Takođe, stranka koja zahteva vansudsko rešenje spora to postiže bez dodatnih troškova i plaćanja sudskih taksi. S druge strane, isticanje imovinsko-pravnih zahteva podnošenjem tužbe nadležnom sudu protiv fizičkog lica ili pravnog lica koja nije državni subjekat uvek ostavlja mogućnost priznanja tužbenog zahteva pre održavanja prvog ročišta i takođe smanjenje troškova na minimum ili postupak medijacije.

\footnotetext{
${ }^{7}$ Vesna Rakić-Vodinelić, „Zakon o parničnom postupku Srbije”, Pravni zapisi, broj 2/2011, str. 536-539.
} 
Zakonskim propisima kojima se uređuje pravobranilačka delatnost predviđeno je da se troškovi zastupanja pred sudovima naplaćuju po advokatskoj tarifi. Brojna su pitanja u vezi s tim, pre svega da li neko ko se finansira iz budžeta ima pravo i na naknadu troškova po advokatskoj tarifi.

Ovakva praksa je osporena pred Evropskim sudom za ljudska prava u Strazburu u predmetu Cindrić i Bešlić protiv Hrvatske. Iako je Sud priznao načelo parničnog postupka da stranka koja izgubi spor plaća troškove, može da štiti državu od nepotrebnih suđenja jer navodi svakog da dobro razmisli pre nego što uloži tužbu, naglasio je da ipak treba da se utvrdi mera u kojoj ovo načelo ograničava osnovna ljudska prava. ${ }^{8}$

Izbor ljudi na čelu organa koji se bave zaštitom imovinsko-pravnih interesa takođe pokazuje šarolikost. Ona se, pre svega, ogleda u postavljenju i imenovanju rukovodilaca koji se nalaze na čelu organa za zaštitu imovinsko-pravnih interesa. U nekim zemljama njihov izbor vrši premijer uz potvrdu parlamenta, u drugim Vlada na predlog ministra pravde, dok je u trećim njihov izbor u nadležnosti Skupštine kao organa zakonodavne vlasti. Razlika se, pre svega, ogleda u tome da li je izbor u nadležnosti organa izvršne ili zakonodavne vlasti, ali je zajedničko da kao državni organ ne uživa garancije nezavisnosti i nepristrasnosti koje su dodeljene sudu i tužilaštvu, osim u slučaju Hrvatske gde je zaštita imovinskopravnih interesa poverena tužilaštvu.

Sagledavajući položaj pravobranilaštva kao organa, kako u pogledu njegove samostalnosti, njegovog odnosa sa izvršnom vlašću i odgovornosti njoj tako i u pogledu samih odnosa unutar pravobranilaštva, uočavamo da su to uglavnom od organa državne uprave izdvojeni organi, koji su, međutim, pod snažnim uticajem izvršne vlasti, oličene pre svega u Vladi i Ministarstvu pravde. Razlog za to treba videti u velikom interesu države da se efikasno štite njeni imovinski interesi, $\mathrm{s}$ obzirom na to da neefikasna zaštita državne imovine slabi državu i otežava joj da vrši sve svoje nadležnosti.

\section{4) ZAKLJUČAK}

Kako bi se povećala nezavisnost, nepristrasnost, efikasnost, smanjili troškovi i bolje zaštitili imovinsko-pravni interesi države, neophodno je razmotriti modalitete uređenja pravobranilaštva pre svega kao organa državne uprave sa većim ili manjim stepenom nezavisnosti i samostalnosti ili pak kao deo tužilaštva. Što se tiče efikasnosti potrebno je uvođenje sistema alternativnog rešavanja sporova u redovan rad pravobranilaštva, insistiranje na mirnom rešavanju sporova i zaključenju poravnanja. Pravobranilaštvo bi trebalo da primenjuje alternativne

\footnotetext{
${ }^{8}$ Case of Cindrić and Bešlić v. Croatia, ECHR, application no. 72152/13.
} 
načine rešavanja sporova naročito $s$ obzirom na to da se proces reformi $u$ pravosuđu kreće u tom pravcu. Procesni putevi za to su uglavnom jednaki s tim što, zavisno od posebnosti procesnih sistema i oblasti koje se uređuju različitim resorskim zakonima, posrednička funkcija pravobranilaštava uglavnom neznatno varira od države do države. Time bi se unapredio rad pravobranilaštva, koji je naročito bitan kako zbog procesa evropskih integracija tako i zbog neophodnosti smanjenja priliva predmeta u sudovima, i činjenja sudskog postupka efikasnijim.

Uopšteno gledajući, jasno je da je rad državnih pravobranilaštava od najveće važnosti za unapređenje efikasnosti pravosudnog sistema, obezbeđivanja pravne sigurnosti, osiguranja dostupnosti pravde i za poboljšanje poverenja društva u pravosuđe.

\section{5) LITERATURA}

Jovičić, Olja, „Istorija pravobranilaštva u Srbiji”, Bilten Republičkog javnog pravobranilaštva, br. 2/2013, Intermeks, Beograd.

Mol, Nula, Harbi, Katarina, „Pravo na pravično suđenje: Vodič za primjenu člana 6. Evropske konvencije o ljudskim pravima", Savet Evrope, Beograd, 2007.

Rakić-Vodinelić, Vesna, „Zakon o parničnom postupku Srbije”, Pravni zapisi, broj $2 / 2011$.

\section{PROTECTION OF LEGAL INTEREST IN PROPERTY IN THE COMPARATIVE EXAMPLE OF THE FORMER OF THE SFRY}

Summary: The aim of the research is to determine the organization and jurisdiction of institutions dealing with the protection of legal interests in property in the former republics of the SFRY. The knowledge about this came primarily through the application of the legal-dogmatic method and, where it was considered necessary, through the application of comparative legal, socio-legal, and philosophical methods. The research resulted in findings about the position of institutions dealing with the protection of legal interests in property in the states formed by the former republics of the SFRY, their organization and jurisdiction, selection method, the scope of work, and diversity, which are primarily reflected in positioning the Public Attorney next to one of the branches of government. The conclusion summarizes the results and gives recommendations.

Keywords: representative, counselling, intermediary and institutional functions, interaction, the rule of law. 